\title{
POLYMYOSITIS
}

\section{Clinical investigation in two sisters}

\author{
Margô Gomes de Oliveira Karnikowski', Bruno Rodrigues Veloso Costa², \\ Oscar Francisco Sanchez Osella ${ }^{3}$, Otávio de Tolêdo Nóbrega ${ }^{1}$
}

\begin{abstract}
We present an investigation of a case of polymyositis affecting two sisters of one same parenthood. Their cases have been documented for almost two decades, being investigated by means of a diagnostic protocol which combined clinical findings as well as laboratorial, histopathological and image tests. In both cases, clinical manifestations started in childhood, without signs of involvement of the central and peripheral nervous system. Both patients proved to respond to a therapeutics based on corticosteroids. The degree of relatedness between their parents corroborate the notion that genetic factors may contribute to the development of the disease.
\end{abstract}

KEY WORDS: polymyositis, inflammatory myopathy.

\section{Polimiosite: investigação clínica em duas irmãs}

RESUMO - Apresentamos a investigação de dois casos de polimiosite, ocorridos entre irmãs de uma mesma filiação. Seus casos foram documentados ao longo de quase duas décadas, tendo sido diagnosticados utilizandose de protocolo diagnóstico que combinou achados clínicos, exames laboratoriais, histopatológicos e por imagem. Em ambos os casos, as manifestações clínicas se iniciaram ainda na infância, sendo constatada ausência de acometimento do sistema nervoso central ou periférico. Ambas as pacientes responderam satisfatoriamente a terapia baseada em corticosteróide. 0 grau de parentesco entre os genitores das pacientes sugere que fatores genéticos podem predispor ao desenvolvimento da doença.

PALAVRAS-CHAVE: polimiosite, miopatia inflamatória.

Idiopathic myopathies are a heterogeneous group of acquired muscle diseases which affect 1 in 100,000 individuals ${ }^{1}$. Polymyositis (PM) comprises an inflammatory myopathy that results from an abnormal immune response to skeletal muscle fibers and associated tissues. Activation of auto-reactive T-cytolytic lymphocytes and molecular mimicry are probable mechanisms underlining this pathology². Moreover, the majority of patients diagnosed with PM display high levels of antibodies to self-antigens, such as cell membrane components and nuclear proteins ${ }^{3,4}$. Current diagnosis of PM is assessed by means of compatible clinical findings (proximal muscle weakness) and measurements of serum muscle enzymes, electromyography and muscle biopsy 5 . Even though causes for PM remain undetermined, an increasing awareness that genetic factors are implicated has evolved from different studies ${ }^{6,7}$. In spite of that, the occurrence of more than one case within the same family still consists in a rare event ${ }^{6,8,9}$.

This study has the purpose to describe anamnesis and testing procedures which resulted in the diagnosis of two patients with PM within the same parenthood, and to report treatment and evolution of both patients documented over almost two decades.

\section{CASES}

Patient 1. G.R.V.C., 26 years old female Caucasian, daughter of parents related to the third degree, was born presenting Apgar 10. The very first symptoms of mobility disorder arose at the age of 5 years old as complaints of strong muscular pains in both lower limbs after extenuating physical exercises. At the age of nine, the patient developed the habit of walking on her toe tips, what prompted medical attention. Preliminary analysis revealed generalized hipotony, predominantly on the pelvic and scapular muscles. At this time, the following laboratorial tests

Department of Physiotherapy, Catholic University of Brasilia, Brasilia DF, Brasil; ${ }^{1}$ Ph.D. in Molecular Pathology and Professor of Immunology and Human Genetics; ${ }^{2}$ Medical student; ${ }^{3}$ Ph.D. in Medicine and Professor of Cardiology.

Received 2 January 2002. Accepted 18 March 2002.

Dra. Margô Gomes de Oliveira Karnikowski - Curso de Fisioterapia Prédio São João Bosco (bloco G) - Universidade Católica de Brasília, EPCT Q.S. 7, Lote 1-72030-170 Brasília DF - Brasil.E-mail: nobrega@ucb.br 
were performed: complete hemogram (normal); summary of urine (normal); oxalacetic transaminase $145 \mathrm{UI} / \mathrm{l} \max$ RV $30 \mathrm{UI} /$; p pyruvate transaminase $186 \mathrm{UI} / \mathrm{l}$ (max RV $37 \mathrm{UI} /$ I); lactate dehydrogenase $419 \mathrm{UI} / \mathrm{l}(\max \mathrm{RV} 240 \mathrm{UI} / \mathrm{l})$; creatine kinase (CK) 2,600 UI/I ( $\max R V 70 \mathrm{UI} / \mathrm{l})$; aldolase 26.3 $\mathrm{UI} / \mathrm{I}(\max \mathrm{RV} 7.6 \mathrm{UI} / \mathrm{l})$. X-ray analysis of the lumbar and the sacrum-coccyx regions of the vertebral column yielded normal results.

Studies on nerve-motor conduction revealed no alteration on either latency or amplitude of the action potentials of the nerves studied (median, ulnar and fibular), being the speed of conduction preserved as well. Studies on sensitive conduction of the same nerves have also failed to demonstrate alterations. Nonetheless, quantitative electromyography yielded motor units of greatly reduced length and amplitude, being polyphasic in their majority, mainly on the biceps, deltoid and quadriceps muscles in spite of no signs of denervation. Tomographic analysis failed to demonstrate any intracranial expansive processes either above or below the tentorium as well as absence of any pathological calcifications, attesting a cranium-encephalic status within the parameters of normality. Additional tomographic analysis revealed a similarly healthy vertebral condition, characterized by canal with dimensions and configuration compatible with normality, lacking pathological compression upon the dural sac. All findings above are consistent with a myopathic condition of idiopathic etiology.

Biopsy of biceps and quadriceps were performed under local anesthesia, being samples fixed before histological processing. Both tissues revealed a degenerative process characterized by disorganization of striated muscle fibers with various degrees of atrophy, displaying multiple endomysial infiltrates by polymorphonuclear cells. In some areas, intensive fagocytosis of muscle fibers by inflammatory mononuclear cells could be observed, with signs of bundle regeneration and endomysial fibrosis. Such findings are compatible with a myopathic condition of acute and chronic polymyositis.

Patient 2. M.R.V.C., 23 years old, female, Caucasian, sister of G.R.V.C., was born presenting Apgar 8. The first symptom of mobility disorder arose at the age of nine, by walking with her left foot in valgus. Having in mind her sister's condition, myopathy was taken under consideration. At that time, the following laboratorial tests were performed: complete hemogram with eosinophilia at 9\% (max RV 3\%); oxalacetic transaminase $24.5 \mathrm{UI} /$; pyruvate transaminase $29 \mathrm{UI} /$; lactate dehydrogenase $273 \mathrm{UI/l}$; creatine kinase 1,580 UI//; aldolase $19.7 \mathrm{UI} / \mathrm{l}$. Max RV were as cited previously. X-ray analysis of hands and feet revealed osseous age within the normality. Similarly to her sister's case, studies of nerve-motor conduction have not shown major alterations of either latency or amplitude of the action potentials of the nerves investigated. Accordingly, electromyographic examination confirmed motor units of reduced length and amplitude, largely polyphasic and restricted to the proximal muscles. Biopsies of these muscle revealed an interstitial microscopic aspect similar to the previous case, with several degenerative inflammatory areas and bundles being regenerated. On what concerned its intensity, the degenerative process that was observed in these samples exceeded the severity of the preceding case, in spite of the lower levels of muscular enzymes. The accentuated disappearance of the striated aspect and the formation of large vacuoles in the muscle cells could translate this increased myopathy. Both biochemical evidence and histopathological findings attest an intense myopathic process, greater in severity than the preceding case, and consistent with acute polymyositis.

In both cases, initial therapeutics consisted on oral administration of $60 \mathrm{mg}$ of the corticosteroid prednisone per day, which resulted in marked decrease of the serum enzyme levels within the first month (Fig 1). Dosage was gradually reduced according to the therapeutic response. Nowadays, both patients present stable clinic conditions which allow regular daily activities: walking without assistance, absence of dysphasia and minor difficulty in shifting from the seated to the ortostatic position. Both patients attend to physiotherapy sessions twice a week in order to strengthen the pelvic and scapular musculature. M.R.V.C employs a maintenance dose of $5 \mathrm{mg}$ of corticosteroids in alternate days. G.R.V.C. sustains her medication suspended since October $/ 2000$, following a 16 years period of stable condition under administration of a similar maintenance scheme.

\section{DISCUSSION}

The first reports of polymyositis were based on findings of anamnesis ${ }^{10,11}$. These studies used to generate inaccurate diagnosis since inflammatory myopathies share clinical symptoms such as mialgia, proximal muscle weakness and electromyographic alterations with several other idiopathic forms of myopathy ${ }^{1,12}$. The development of diagnostic protocols that couple laboratorial, histopathological and image procedures has greatly facilitated the precise identification of myopathies with inflammatory etiology ${ }^{13,14}$, what in turn allows hiring an effective therapeutics. In this study, an investigation based on clinical, biochemical and images findings was successfully hired to diagnose polymyositis in two non-twin sisters from the same parenthood.

In both cases, the first clinical signs were observed within childhood. In accordance to a typical myopathic condition, levels of serum muscular enzymes (CK and aldolase) were significantly elevated in preliminary tests. Electromyographic abnormalities confirmed a myopathic status which was not correlated to any detectable cranium-encephalic or neurological disturbances, whose normality was attested by tomographic as well as nerve conduction analysis. 


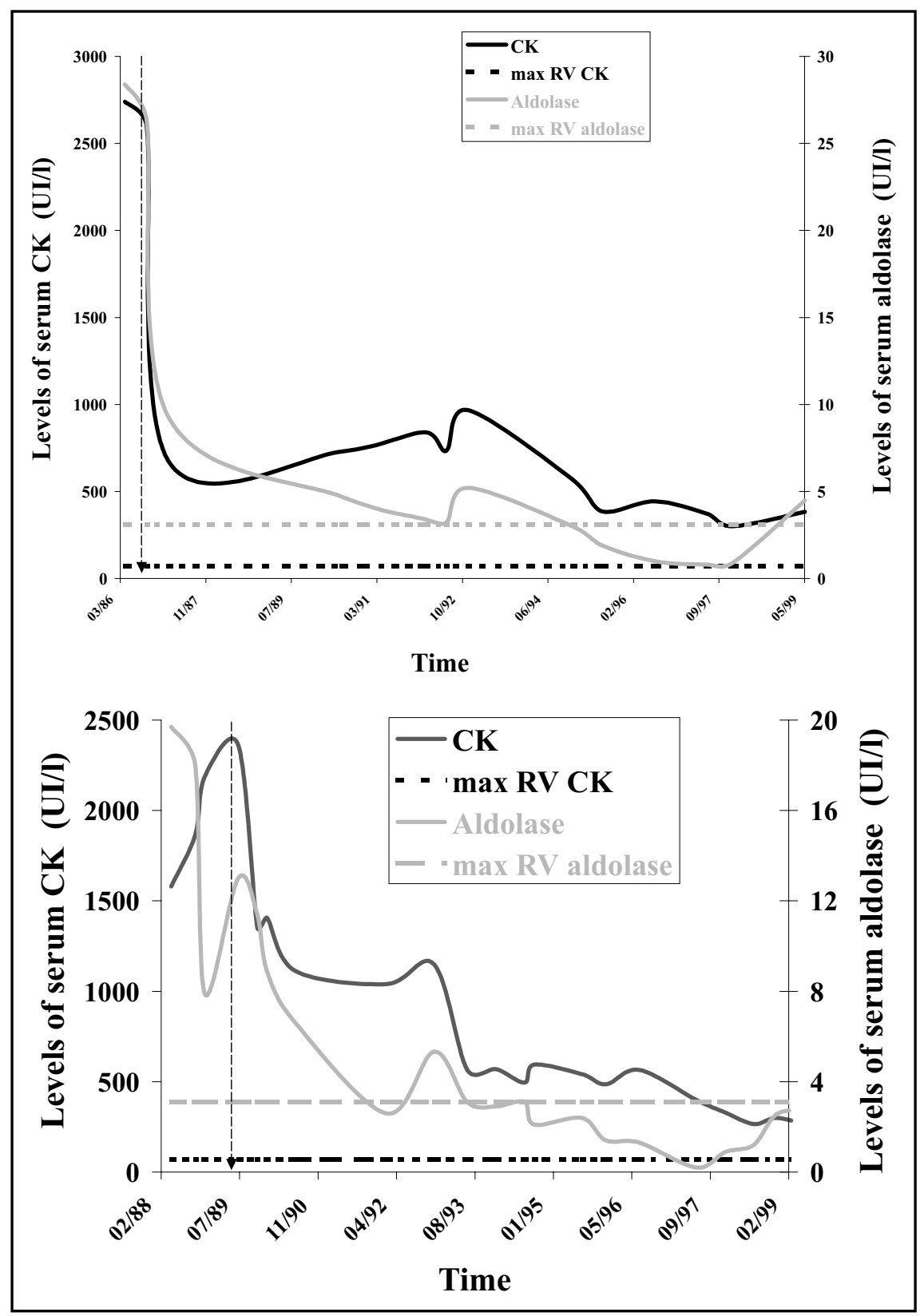

Fig 1. Levels of the muscular enzymes CK (left axis) and aldolase (right axis) in the serum of both patients, G.R.V.C. (A) and M.R.V.C. (B), throughout the treatment with corticosteroid. Each solid line represents the union between independent dosages of $C K$ (black line) and aldolase (gray line) determined over the time. Horizontal dotted lines represent maximum referential values (max RV) for each enzyme. A vertical dotted arrow indicates the beginning of the treatment of each patient.

In addition, histopathological analysis of proximal muscle biopsies of each patient revealed an intense degenerative process characterized by marked inflammatory infiltrates, showing a clinical condition compatible with PM. Nonetheless, symptoms usually associated to inflammatory myopathies such as fever, dysphasia and arthralgia ${ }^{12,13}$ have not been observed. Exclusion of dermatomyositis (DM) was possible based on the absence of cutaneous involvement in ei- ther patients. Both cases proved to respond to a therapeutics of corticosteroids, noticed the great reduction of the serum muscle enzymes within the first month of treatment (Fig 1). In spite of the long-term administration of steroids, periodic osseous densitometry revealed no major pathological alterations of their bone constitution.

Despite the fact that the etiology of PM remains undetermined, different factors have been correlated 
with the origin of inflammatory myopathies. Some studies implicate viral and bacterial infections as possible triggering factor of the pathogenic process $^{9,15,16}$. Others enroll immune disturbances and genetic profiles as causative determinants for the onset of PM and DM. In the latter, disruption of immunological tolerance is considered a factor that probably accounts to the development of muscular lesions, since such lesions may consist in a pathological outcome of the autoantibodies found in a significant number of patients with $\mathrm{PM}^{6,17}$. In addition, the augmented frequency of the HLA-B8 and DR3 haplotype among patients diagnosed with this pathology suggests that a genetic profile may predispose to the its onset ${ }^{18}$. In the present study, both patients are sisters from one same parenthood, where the parents are cousins in first degree. It is noteworthy that related individual share sets of haplotype and that, for this reason, consanguine unions tend to predispose their descendants to the onset of recessive and multifactorial phenotypes. Thus, even though a definitive relationship between immunogenetic factors and polymyositis has not been established, we consider that the cases reported in this study corroborate such an association.

The comprehension that the immune system works as an agent that ensures the equilibrium within the organism implies that its disturbance allows or generates unbalance. In autoimmune diseases, it is desirable to apply medicinal treatments that contribute to the recovery from the unbalanced state. In the cases above, treatment with corticosteroid proved to be appropriate for such purpose, considering that patient G.R.V.C. remains with a stable condition despite of having her medication suspended for one year. Nonetheless, it is important to emphasize the need for an early and accurate diagnosis of inflammatory myopathies, so that an appropriate therapeutics may take place around the dawn of the pathological process to allow satisfying outcomes, similar to those described in this study.

Acknowledgments - The authors gratefully thank both patients and their family for the consent on this study, and the Catholic University of Brasilia for providing the environment for its development.

\section{REFERENCES}

1. Dalakas MC. Polymyositis, dermatomyositis and inclusion-body myositis. N Engl J Med 1991;325:1487-1498.

2. Miller FW, Love LA, Barbieri SA, Balow JW, Plotz PH. Limphocyte activation markers in idiopathic myositis: changes with disease activity and differences among clinical and auto-antibodies subgroups. Clin Exp Immunol 1990;81:373-379.

3. Bluthner M, Bautz FA. Cloning and characterization of the cDNA coding for a polymyositis-scleroderma overlap syndrome-related nucleolar $100 \mathrm{kDa}$ protein. J Exp Med 1992;176:973-980.

4. Ge Q, Frank MB, O’Brien C, Targoff IN. Cloning of a complementary DNA coding for the $100 \mathrm{kDa}$ antigen protein of the PM-Scl autoantigen. J Clin Invest 1992;90:559-570.

5. Matsui K, Aizawa Y, Inoue K, Yaguchi H, Toda G. Polymyositis with marked paravertebral muscle atrophy in patients with primary biliary cirrhosis. Rinsho Shinkeigaku 2000;40:694-700.

6. Rider LG, Gurley RC, Pandey JP, et al. Clinical, serological, and immunogenetic features of familial idiopathic inflammatory myopathy. Arthritis Rheum 1998;41:710-719.

7. Garlepp MJ. Genetics of the idiopathic inflammatory myopathies. Curr Opin Rheumatol 1996;8:514-520

8. Lewkonia RM, Buxton PH. Myositis in father and daughter. J Neurol Neurosurg Psychiatry 1973;36:820-825.

9. Hokezu Y, Higuchi I, Yanai S, Nagai M, Nagamatsu K. A family case of HAM and HTLV-I carrier including two sisters presenting with myositis. Rinsho Shinkeigaku 1994;34:563-568.

10. Bohan A, Peter JB. Polymyositis and dermatomyositis. N Engl J Med 1975;292:344-347,403-407.

11. Bohan A, Peter JB. A computer assisted analysis of 153 patients with polymyositis and dermatomyositis. Medicine 1977; 56:255-286.

12. Plotz PH, Dalakas M, Leff RL, Love AA, Miller FW, Cronin ME. Current concepts in idiopathic inflammatory myopathies: polymyositis, dermatomyositis, and related disorders. Ann Interm Med 1989;111:143157.

13. Scola RH, Werneck LC, Prevedello DMS, Toderke EL, Iwamoto FM. Diagnosis of polymyositis and dermatomyositis: a study of 102 cases. Arq Neuropsiquiatr 2000;58:789-799.

14. Hilário, MOE, Yamashita H, Lutti D, Len C, Terreri MT, Lederman H. Juvenile idiopathic inflammatory myopathies: the value of magnetic resonance imaging in the detection of muscle involvement. Sao Paulo Med J 2000;118:35-40.

15. Dalakas MC. Immunopathogenesis of inflammatory myopathies. Ann Neurol 1995;37:S74-S86.

16. Oliveira HA, Macieira JC, Fakhouri R. Polimiosite associada a infecção por HTLV-I. Arq Neuropsiquiatr 2000;58:935-938.

17. Miller FW. Myositis-specific antibodies: touchstones for understanding the inflammatory myopathis. JAMA 1993;270:1846-1849.

18. Garlepp MJ. Genetics of the idiopathic inflammatory myopathies. Curr Opin Rheumatol 1996;8:514-520. 